\title{
ASSOCIATION OF ONTARIO LAND SURVEYORS
} (ADVERTISEMENT SPONSOR)

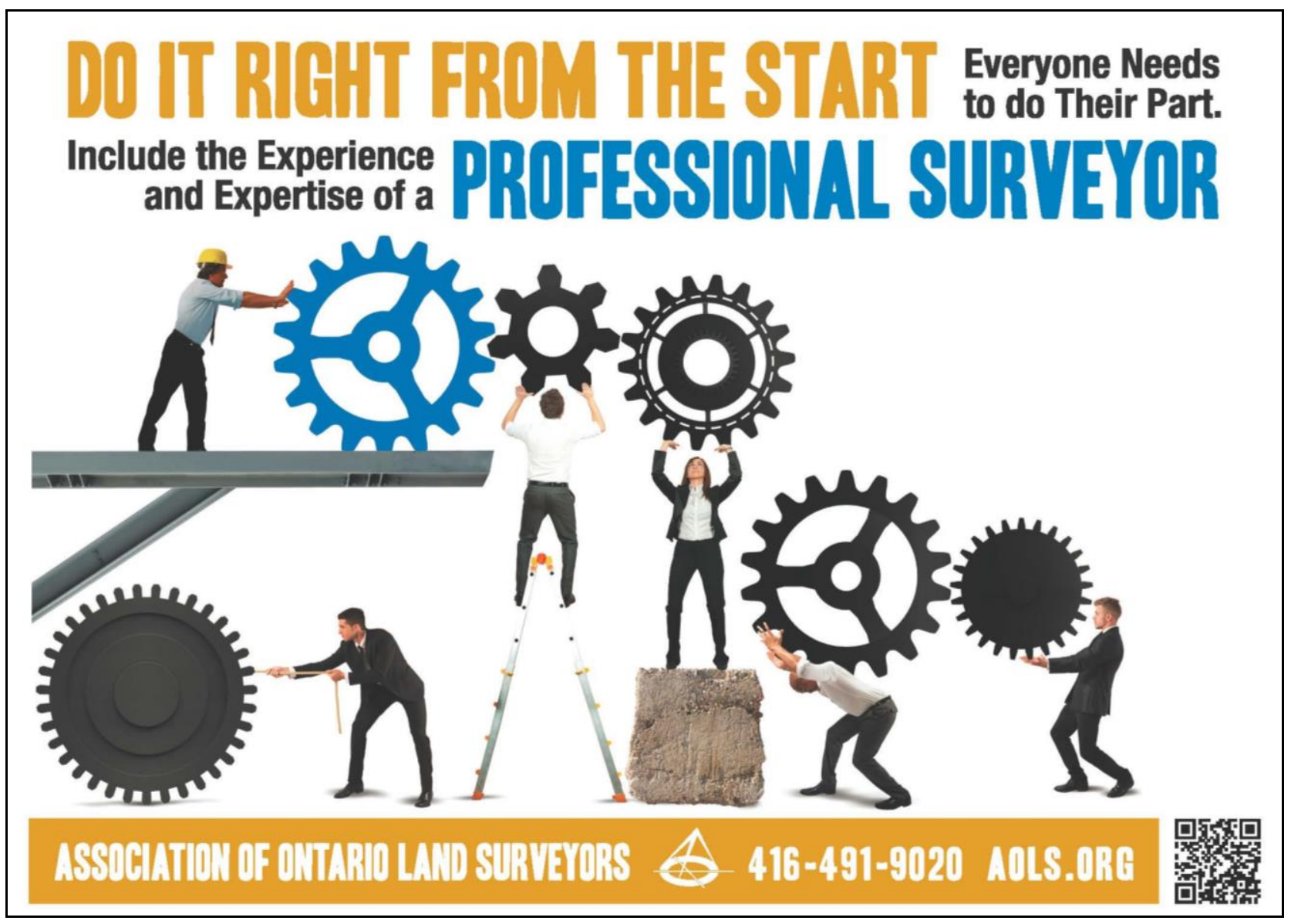

